\title{
Ekoköylerde Yer Seçimi İle İlgili Karar Süreçleri Üzerine Bir Araştırma
}

\author{
Osman ZEYBEK ${ }^{1^{*}}$ \\ ${ }^{1}$ Bursa Uludağ Üniversitesi Ziraat Fakültesi Peyzaj Mimarlığı Bölümü, BURSA
}

\section{Öz}

Bir ekoköy projesi başlatırken akla gelen en önemli sorulardan birisi, bu projenin nerede hayata geçirilmesi gerektiğidir. Projenin başlatılması ve bitirilip hayata geçirilmesi arasındaki süreçte en çok dikkat edilmesi gereken adımın yer seçimi olduğu gibi bir düşünce yaygındır. Özellikle, böyle bir projenin korunan alanlarda, milli parklar içinde, ya da ekolojik karakterleri açısından son derece zengin bölgelerde hayata geçirilmesi gerektiğine dair yaygın bir kanı olduğu görülmektedir. Bu görüşün doğru olup olmadığını daha iyi analiz edebilmek için, dünyanın her köşesinden farklı hikâyeleri olan ve önemli başarılar elde etmiş ekoköylerin kuruluş aşamasında yer seçimi ile ilgili karar süreçlerine bakmak sağlıklı olacaktır. Bu çalışmada hem boş bir alanda kurulan ekoköy örneklerine hem de mevcut bir yerleşkeyi ekoköye dönüştürme projelerine örnek olacak, dünyanın farklı yerlerinden ekoköyler irdelenerek kuruluş aşamaları araştırılmıştır. Bu bilgiler 1şı̆̆ında, ekoköy projeleri için yer seçimine dair, araştırılan komünlerin deneyimlerinden yola çıkarak tespitlerde bulunulmuştur.

Anahtar Kelimeler: Ekoköy, ekoköy akımı, yer seçimi, karar süreci, niyet komünleri.

\section{A Research on the Decision Processes Related to the Selection of the Place in Ecovillages}

\begin{abstract}
One of the most important questions that comes to mind when launching an eco-village project is where this project should be passed on. It is a common idea that the most important step in the process of initiating the project, finishing it, and passing it on is choosing the place. In particular, it appears that there is a widespread belief about such an ecological project should be passed on in protected areas, national parks, or in areas which are rich in ecological characteristics. In order to better analyze whether this view is correct, it would be healthy to look at the decision-making process of location selection of ecovillages with different stories from all corners of the world, which have achieved significant success. In this study, ecovillages are investigated by examining their enterprise phases, which can be sampled in both transition projects and from zero to an ecovillage projects from all over the world. Along with the information compiled, experiences of those intentional communities that have been researched shed light on some determination about location selection for ecovillage projects.
\end{abstract}

Keywords: Ecovillage, ecovillage movement, location selection, decision process, intentional communities.

\begin{tabular}{ll}
\hline *Sorumlu Yazar (Corresponding Author): & Geliş (Received) : 10.01 .2020 \\
Osman ZEYBEK (Araş. Gör.); Bursa Uludağ Üniversitesi Ziraat Fakültesi Peyzaj & Kabul (Accepted) : 18.03.2020 \\
Mimarllğı Bölümü, 16059, Bursa - Türkiye. Tel: +90 (224) 2941634, & Basım (Published) : 15.04.2020 \\
E-mail: osmanzeybek@ uludag.edu.tr. ORCID: 0000-0002-2752-407X &
\end{tabular}




\section{Giriş}

Ekoköyler, birbirleriyle, diğer canlılarla ve dünyayla bir uyum içerisinde yaşamaya çalışarak sürdürülebilir bir yaşam için çaba gösteren girişimcilerin yaşadığı yerlerdir. Amaçları, destekleyici bir sosyal ve kültürel çevreyi düşük etkili bir yaşam biçimiyle birleştirmektir. Yeni bir sosyal yapı olarak, ekoköy, bugünün şehir yaşamı karşısındaki kırsal yaşam anlayışının ötesine geçmektedir. 21. yüzyılda insan yerleşimlerinin planlanması ve yeniden düzenlenmesi için geniş bir uygulama alanı sağlamaktadır (Jackson and Svensson 2002).

Dawson'a göre (2006), her ekoköy yerleşiminin hitap ettiği topluluk ve kuruluş yöntemleri birbirinden farklıdır. Lokasyon, arazi seçimi, yerin coğrafi özellikleri ve kurulum amaçları ile değişkenlik göstermektedir.

Genellikle ekoköyler niyet komünleri tarafindan hayata geçirilmektedir. İyi eğitim almış ve dünyanın bozulan dengesine daha fazla zarar vermek istemeyen gruplar, arazi satın alıp ekoköy çalışmalarına başlarlar. Ya da yaşadıkları bölgenin iklim koşulları kötüleşmeye başlayan insanlar, burayı terk etmek yerine kalıp mücadele etmeyi, doğayı onarmayı denerler. Kimi örneklerde bu uygulamaların devlet kanalıyla da desteklendiği görülmektedir. Hatta başarılı bazı ekoköyler Bileşmiş Milletler ve UNESCO tarafından da koruma altına alınarak finansal destek sağlanmaktadır.

Oluşumlarına göre ekoköyler boş bir alanda tesis edilen ekoköyler ve mevcut bir yerleşkeyi ekoköye dönüş̧ürme projeleri olmak üzere iki grup altında sınıflandırılabilir. Her iki yöntemle de başarılı ekoköyler oluşturulabilmektedir. Hangi yöntem tercih edilirse edilsin, bir ekoköy projesi başlatmadan önce akla gelen ilk sorulardan birisi yer seçimi olmaktadır.

Küresel Ekoköy Ağına göre (Global Ecovillage Network), ekoköyler, sürdürülebilirliğin dört boyutu üzerine inşa edilirler. Ekolojik, ekonomik, sosyal ve kültürel açıdan sürdürülebilirliğin sağlandığı yerleşimler başarılı birer ekoköy olabilmektedir (GEN, 2020). Bir ekoköy girişiminin en önemli aşamalarından birisi olan yer seçimi, ekoköyün sürdürülebilirliğini son derece etkileyen parametrelerden birisidir. Seçilen yerin ekolojik nitelikleri, girişimin ekonomisini de kültürel karakterini de etkilemektedir. Bu çalışmada, ekoköy girişimimlerinin yer seçimi aşamasında nasıl bir yol izledikleri araştırılmıştır.

\section{Materyal \& Yöntem}

Bu çalışmada, farklı hikâyelere sahip 10 ekoköyün yer seçimi aşamaları araştırılmış ve bu aşamadaki karar mekanizmaları üzerinde durulmuştur. Araştırma süresinde, diğer pek çok ekoköyün resmi internet sitesi ve ilgili kaynaklar incelenmiştir. Bunlar arasında İsrail'deki Kibbutz Lotan, Rusya'daki Kitezh, İtalya'daki Damanhur, ABD'deki The Farm, Earthaven ve Los Angeles EV, Japonya'daki Konohana ve Kobunaki, Danimarka'daki Svanholm ekoköyleri bulunmaktadır.

Kuruluş aşamasında, yer seçimi ile ilgili karar süreçlerine dair yeterli bilgiye ulaşılan 10 ekoköy bu çalışmanın materyalini oluşturmuştur. Araştırmaya dahil edilen ekoköyler kuruluşlarına göre sınıflandırılmıştır. Bu kapsamda, boş bir alanda niyet komünleri tarafından tesis edilen ekoköyleri temsilen Ithaca ekoköyü (ABD), Auroville (Hindistan), The Village (İrlanda), Findhorn (İskoçya), Crystal Waters (Avustralya) seçilmiştir. Mevcut bir yerleşkeyi ekoköye dönüştürme projeleri kapsamında ise Sieben Linden (Almanya), Mbam ekoköyü (Senegal), Solheimar (İzlanda), COLUFIFA (Senegal, Gine, Gambiya), ZEGG (Almanya) seçilmiştir.

İncelenen ekoköylerin yer seçimi ile ilgili karar süreçlerine dair gerekli bilgilere, resmi internet sitelerinden ulaşılmaya çalışılmıştır. Resmi internet sitelerinde yer seçimi ile ilgili yeterli bilgi vermeyen ekoköylerin, iletişim amaçlı e-posta adresleri aracılığıyla, her birine neden özellikle bulundukları yeri proje için uygun gördükleri, yer belirleme aşamasında hangi faktörlerin etkili olduğu sorulmuştur. Derlenen yanıtlar, araştırma bulguları bölümünde değerlendirilmiştir.

\section{Araştırma Bulguları}

\subsection{Boş Bir Alanda Tesis Edilen Ekoköyler}

Bu başlık altında irdelenen ekoköyler, genellikle dünya sağlığının kötüye gitmesinden muzdarip ve iyi eğitim almış, hayat standartları yüksek insanlar tarafindan (bu insanların oluşturdukları topluluklara niyet komünleri denmektedir) komünal girişimler olarak başlatılmıştır. Yer seçimi ile ilgili hemen hemen hepsinin hikâyesi benzerdir. Bu insanlar bir araya gelip, genellikle hayatlarını sürdürdükleri kente yakın bir arazi satın alarak 
ekoköy oluşturma projelerine başlamaktadırlar.

\section{- Ithaca Ekoköyü}

EVI $^{1}$ New York'un banliyösünde, metropolün etkisinin hissedildiği bir bölgede Kuzey Amerika'nın en ünlü ekoköyü olmayı başarmıştır. Birçok kaynakta kentsel ekoköyler sınıfında değerlendirilmektedir (Şekil 1).

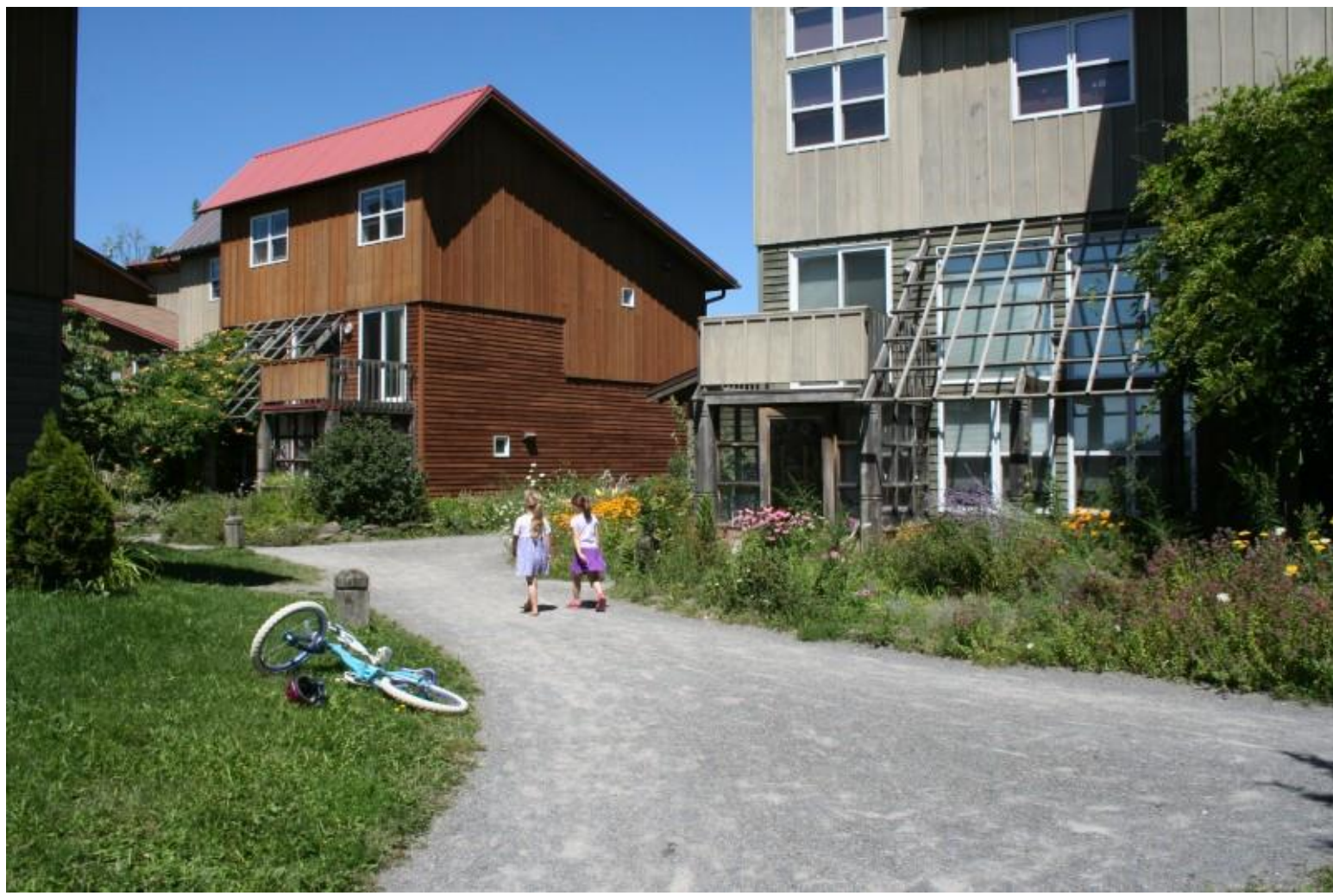

Şekil 1. Ithaca ekoköyü (www.ecovillageatithaca.org).

Ithaca ekoköyü kurucularının, projenin başından beri en fazla önem verdikleri şey orta sınıf Amerikan vatandaşları tarafından kolayca kopyalanabilir bir örnek oluşturmaktır. EVI'nin hedeflerini koyduğu ilk bildirilerden biri bunu açıkça ortaya koymaktadır: "EVI'nin nihai hedefi, insan yerleşimlerinin tekrar tasarlanmasıdır. Biz, sürdürülebilir bir yaşam için sadece kullanışlı değil, aynı zamanda kolayca tekrarlanabilen sistemlere örnek oluşturacak yaklaşık 500 kişilik bir topluluk modeli yaratıyoruz” (Bokaer 1991).

EVI'yi yaratma fikri, 1989 - 1990 yılları arasında "Yaşanabilir Bir Dünya İçin Küresel Yürüyüşs”, adlı, Amerika Birleşik Devletleri'nin bir kıyıdan öbür kıyıya kadar geçildiği (New York’tan Los Angeles'a) yürüyüş sırasında ortaya çıkmıştır. Dönüş yolunda yürüyüşün öncülerinden bazıları Kuzey Amerika'nın en tanınmış ekoköyünün ortaya çıkmasına yol açacak süreci başlatmıştır. 1991 yılındaki ilk vizyon geliştirme toplantılarında yaklaşık 100 kişi ağırlanmış ve hedeflerin belirlenmesi, satılık arazi arama, yasal konular ve fon bulunması gibi konuları araştırmak üzere komiteler oluşturulmuştur. Bir sonraki sene içinde New York eyaletindeki Ithaca şehrine üç kilometre uzaklıkta yarı kırsal bir arazi bulunmuştur. EVI, destekçilerinin verdiği kaynakla 70 dönüm arazi satın almış, ekoköyün tasarım ile kuruluş süreçlerinin merkezden yönetilmesine ve bu yeni yerleşimin ortak konut modeli çizgisinde tasarlanmasına karar verilmiştir (Bokaer 1991). Fundraising ${ }^{3}$ ile Eylül 1991'de yaklaşık 400.000 \$ yardım toplanmıştır. Mart 1992'de ekoköyde ev inşa edip yaşamak isteyen 50 kişi ile toplantılara başlanmıştır. 23 Haziran 1992'de ise 172 dönümlük arazi satın alınmıştır. Kasım 1996'da ise ekoköyde yaşam başlamıştır (Walker 2016).

Joan Bokaer'in editörlüğünü yaptığı, Cornell Üniversitesi’nden katılımcıların desteği ile hazırlanan Ithaca

\footnotetext{
${ }^{1}$ Ing. Ecovillage at Ithaca.

${ }^{2}$ Ing. Global Walk for a Livable World.

${ }^{3}$ Fundraising: hedeflerin açıklandığı çeşitli yazılı ve görsel mesajlar yoluyla birçok insana ulaşıp, bağış yapmalarının talep edildiği bir tür para toplama yöntemi. Crowdfunding de benzer bir uygulamadır.
} 
Ekoköyü - Alan Koruması ve Sürdürülebilir Mahalle Gelişimi Modeli ${ }^{4}$ isimli çalışmada (1991), neden Ithaca bölgesini seçtiklerine dair fikirleri paylaşmıştır (s6 - 7):

"Ithaca, New York eyaletinin merkezine yakın, Finger Lakes (parmak göller) bölgesinde yer almaktadır. Bu biyobölge oldukça zengin bir yapıya sahiptir. Alan civarında eyalet parklarl, Five Finger Lakes (Beş Parmak Gölleri), göletler, ıslak alanlar, vadiler, orman rezervleri, yaban hayatı koruma alanları ve tarımsal alanlar bulunmaktadır. Kırsal bir alanda gibi görünmektedir ancak Cornell Üniversitesi, Ithaca Koleji ve diğer birkaç kolejin çok yakında bulunması nedeniyle kozmopolit bir kimliğe sahiptir. Bu faktörler kültürel çevreyi de zenginleştirmektedir. Cornell topluluğunda, 149 farklı ülkeden ögrenci ve eğitmen bulunmaktadır. Arazi fiyatları da makul seviyededir. Bölgedeki doğal ve kültürel varlıklar, alanda bir ekoköy önermek için fazlasiyla yeterlidir. Ithaca'da yaşayan insanlar da bu doğal çevreyi koruma konusunda oldukça hassas davranmaktadır. Dolayısıyla bu bölgede kurulacak bir ekoköyün, Ithaca bölgesinde yaşayan insanlar tarafindan da saygl ve hevesle karşılanacağı düşünülmüştür. ”

Yukarıda açıklanan teknolojik ilerlemenin ve sosyal uyumun yakınlaşması, 1990'ların "eylemin on yılı" (harekete geçilen on yıl) olduğunu göstermektedir. Bu gündem göz önünde bulundurulduğunda, $\mathrm{CRESP}^{5}$ 'in bir projesi olan Citizen Network $^{6}$ (Vatandaş Ağ $)$, Ithaca'nın yakınında inşa edilecek bir ekolojik ve kooperatif köy modelinin kurulmasına öncülük etmek istemektedir. 177 dönümlük arazide en fazla 500 kişinin yaşayabileceği bir ekoköy modeli oluşturulmaya başlanmıştır. (Burada plan aşamasından bahsedilmektedir. Proje hayata geçirilmeye başlandığında 172 dönümlük arazi satın alınmıştır.)

Raporda net bir şekilde bahsi geçmese de, Ithaca ekoköyünün öncüleri hâlihazırda New York’ta yaşamaktaydı. Dolayısıyla projenin hayata geçirilme aşamasında kolaylıkla alana gidip gelebildiler. Yani bu bölgenin proje alanı olarak seçilmesindeki temel faktörlerden birisi de yakınlık olmuştur. Yine de bu bölgenin New York eyaleti içinde ekolojik açıdan en iyi durumda olan arazileri barındırması, seçilmesinde etken olmuştur.

\section{- Auroville Ekoköyü}

Auroville, Hindistan'ın güneydoğusunda yer alan, en kalabalık ekoköy olarak bilinen bir yerleşimdir (Şekil 2). 1968'de kurulan bu ekoköy 50. yılını kutlamaktadır. 50.000 insanın yaşayabileceği, sürdürülebilir bir yerleşim modeline dönüşmeyi hedefleyen Auroville'in güncel nüfusu 2500 civarındadır. 1930 - 1960 yılları arasında fikirsel gelişimini tamamlayan yerleşim, 1966 'da proje aşamasındayken UNESCO tarafından insanlığın geleceğine önemli bir proje olarak övgüye değer bir uygulama olduğu belirtilmiş ve ardından tam teşvik sağlanmıştır (Auroville, 2018).

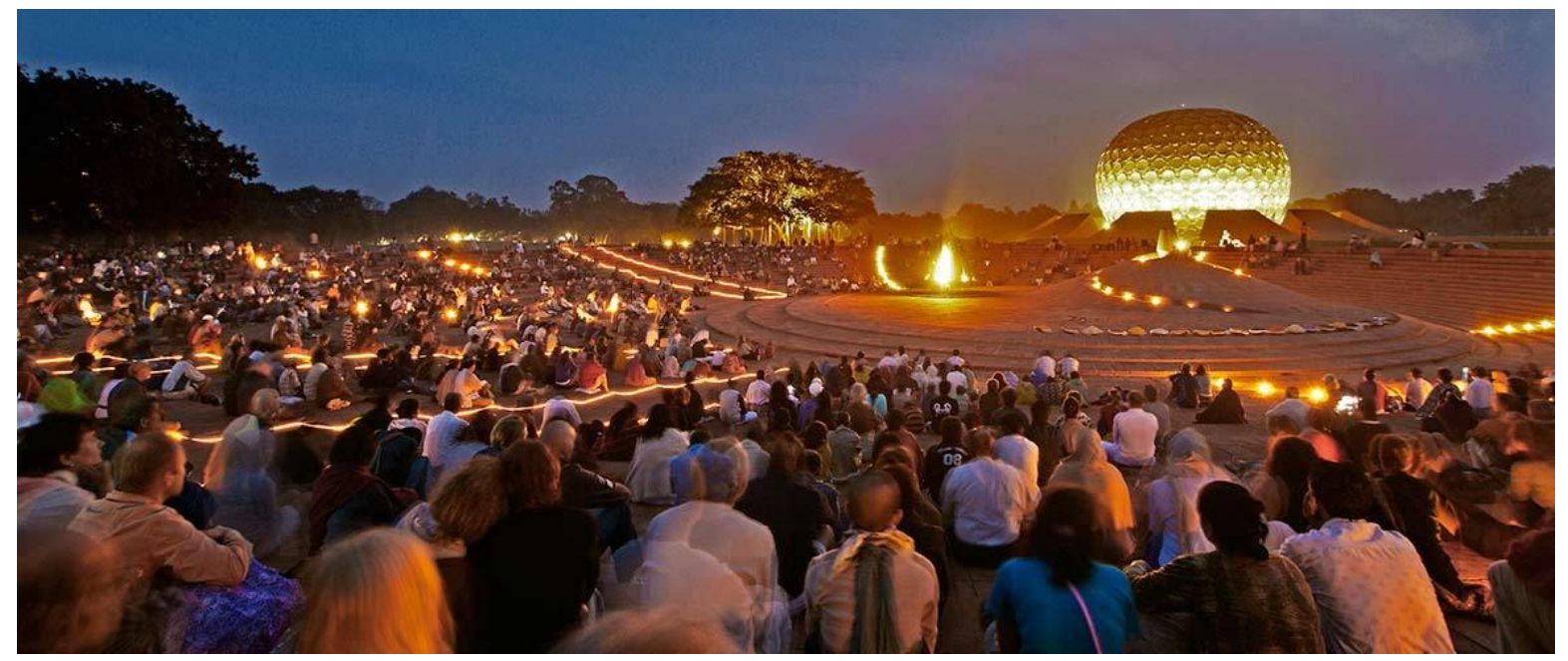

Şekil 2. Auroville ekoköyü (www.auroville.org).

Auroville'in hikâyesindeki ana karakter Mira Alfassa'dır (1878 - 1973). Türk bir baba ve Mısırlı bir annenin

\footnotetext{
4 Ing. Ecovillage at Ithaca - A Model For Land Conservation and Sustainable Neighbourhood Development.

${ }^{5}$ CRESP: Center for Religion, Ethics and Social Policy at Cornell University (Cornell Üniversitesi Din, Etik ve Sosyal Politikalar Merkezi). Bu merkez çatısı altında ayrıca Citizen Network, Eco-Justice, Oikos ve Green Enterprise Institue gibi kuruluşlar da hayata geçirilmiştir.

${ }^{6}$ Citizen Network: Bir CRESP projesidir. Misyonu, insan yerleşimini gezegenin yaşam destek sistemleriyle uyumlu hale getirmektir.
} 
çocuğu olarak Fransa'da dünyaya gelmiştir. Auroville'in resmi internet sitesinde yer seçimi konusunda net fikirler bulunmasa da, Mother olarak andıkları Mira Alfassa'nın spritüal deneyimleri sonucu bu mekânın seçildiğine dair yazılar mevcuttur.

Auroville'in resmi internet sitesindeki arşiv bölümünde belirtilen e-posta aracılığıyla iletişime geçerek, neden bulunduğu yerin önemli olduğuna dair daha net bilgilerin olup olmadığı sorulmuştur. Arşivden sorumlu Gilles Guigan, oldukça uzun bir e-posta ile sorunun cevabının kuruluş hikâyesinde gizli olduğunu anlatmıştır. Özetle, Mira Alfassa, spritüal partneri Sri Aurobindo ile 1920'de Fransa'da tanışmıştır. Oldukça ilginç hikayeleri olan bu iki insan, ruhani bir aydınlanma sonrası dünyaya Auroville gibi bir miras bırakmadan ölmemeleri gerektiğine karar vermişlerdir. Sri Aurobindo'nun 1950'de Fransa'da hayatını kaybetmesinin ardından Mira Alfassa meditasyonları sırasında, o dönem Fransa'nın sömürgesinde bulunan Hindistan'ın güney bölgelerinde, Hindistan'da oldukça kutsal sayılan banyan ağacı (Ficus benghalensis) vizyonu görmektedir. Hindistan'a giderek, orada çeşitli kurumların desteğini alıp Fransa'dan da bir grup mimar arkadaşını davet etmesinin ardından bulduğu dev bir banyan ağacını merkez alarak Auroville’i tasarlamaya başlamıştır.

Bu bilgilere dayanarak Auroville'in yer seçiminde, bir Fransız vatandaşı olan Mira Alfassa'nın, Hindistan'ın Fransız sömürgesinde bulunan güney bölgelerine istediği zaman girip çıkabilmesinde payı olduğu yadsınamaz. Auroville, her ne kadar bitki ve hayvan tür sayısı açısından zenginliği, kişi başına düşen verimli ıslak ve kara alanlarının çokluğu ile bilinse de oldukça hassas ve kırılgan bir iklimde yer almaktadır. Seçilen bu mekân ekolojik açıdan son derece zengin olsa da, 2007'de Muson mevsiminde ekoköyün \%70'i yıkılmış, ertesi yıl tekrar inşa edilmiştir (Auroville, 2018). Bu açıdan birçok ekoköy vizyonerinin savunduğu gibi, ekoköyler sadece insanların kolay ayak uydurabileceği, her açıdan zengin coğrafyalarda değil, bilakis zorlu coğrafyalarda da kurularak, civardaki insanlara sürdürülebilir, zengin bir yaşam formu oluşturulabileceğini göstermelidir. Auroville, kurulduğu mekânda var olma savaşı verirken misyonları arasında bundan da bahsetmektedir.

\section{- The Village (Cloughjordan ecovillage)}

2006'da inşaat süreci başlayan İrlandalı girişimin fikirsel ortaya çıkışı 1990'a dayanmaktadır. 1990'ların sonunda çekirdek grubu oluşturan üyeler Dublin'de toplantılara başlamış ve öncelikle boş bir arazi bulmaya odaklanmışlardır (Şekil 3).

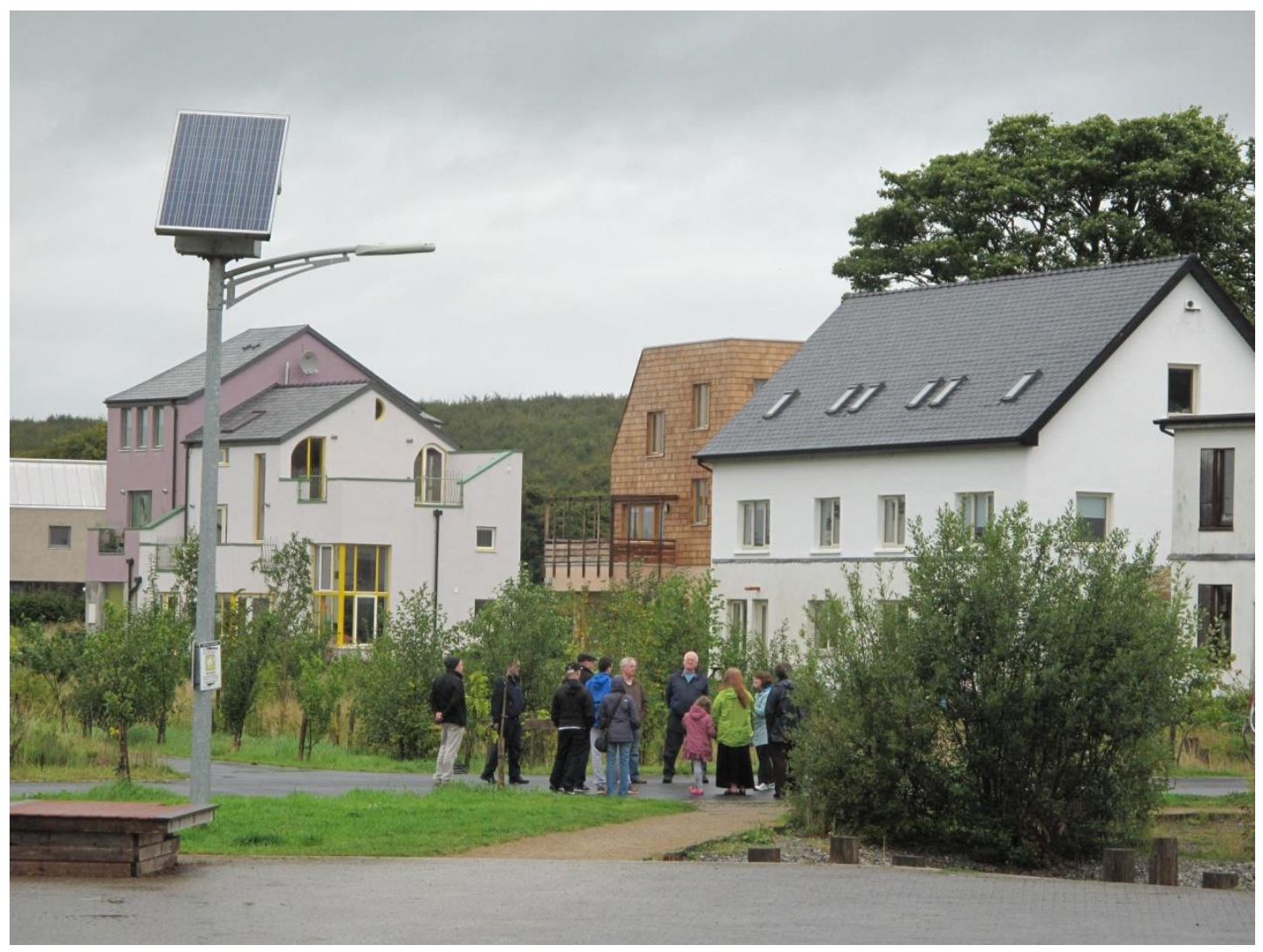

Şekil 3. The Village / Cloughjordan ekoköyü (www.thevillage.ie). 
Planlama izni olan bir arazi bulmakta zorlanınca, bir uzman yardımına ihtiyaç duydukları konusunda hemfikir olarak, bu işleri yürütebilmesi için bir tapu- kadastro memuru ile anlaşmışlar, sonrasında mekânın tasarımında yardımını almak üzere bir mimara danışmışlardır. Planlamanın tamamlanıp ortaya çıkması ve yarı zamanlı tuttukları memurun ve mimarın başarılı PR çalışmaları ile proje, yasal organlar tarafindan biraz daha ciddiye alınmaya başlanmış ve 2002'de Cloughjordan köyünün yakınındaki bir arazide bir ekoköy kurulmasına izin verilmiştir. Bazı kaynaklarda The Village, Cloughjordan ekoköyü olarak da geçmektedir. Bu arazi, üzerinde topluluk binası, oyun alanları, bisiklet ve yürüyüş yolları gibi 100 hizmet bölgesi kurulabilecek, ayrıca tarım ve doğal yaşam alanlarına da olanak veren, 27 dönümlük büyük bir parseldir. 2005'de 67 hektarlık alan daha satın alınmış ve ekoköyün yakın çevresinin planlanması için hükümetten izin alınmıştır. 2009'da ise ilk yerleşimciler alana taşınmıştır (The Village, 2018).

\section{- $\quad$ Findhorn}

Findhorn'un hikayesi 1962'de, daha önceden bahçecilik deneyimi olmayan üç ruhani arayışçı İskoçya'daki Kuzey Denizi’nde çorak, rüzgârlı bir uçurumu bereketli bir yere dönüştürdüğünde başlamıştır. Başarılarını doğa ile kurdukları doğru ilişkilere atfeden bu grup kısa süre içinde büyüyerek, bilimsel kriterlerle açıklanamayan hayret verici başarıları ile tüm dünyada duyulmuştur. 1970'lere kadar Findhorn, New Age hareketindekilerin Mekke'si haline gelmiştir. Findhorn üyeleri şu anda Birleşmiş Milletler ve çok uluslu şirketlerde danışman olarak çalışmaktadır (Şekil 4). Günümüzde yaygın ölçüde “ekoköylerin anası” olarak görülmektedir. Findhorn'un başarısının asıl sırrı belki de, uzun zaman önce odağını sebze yetiştirmekten "insan yetiştirme”ye çevirmesi olmuştur (Litfin, 2017).

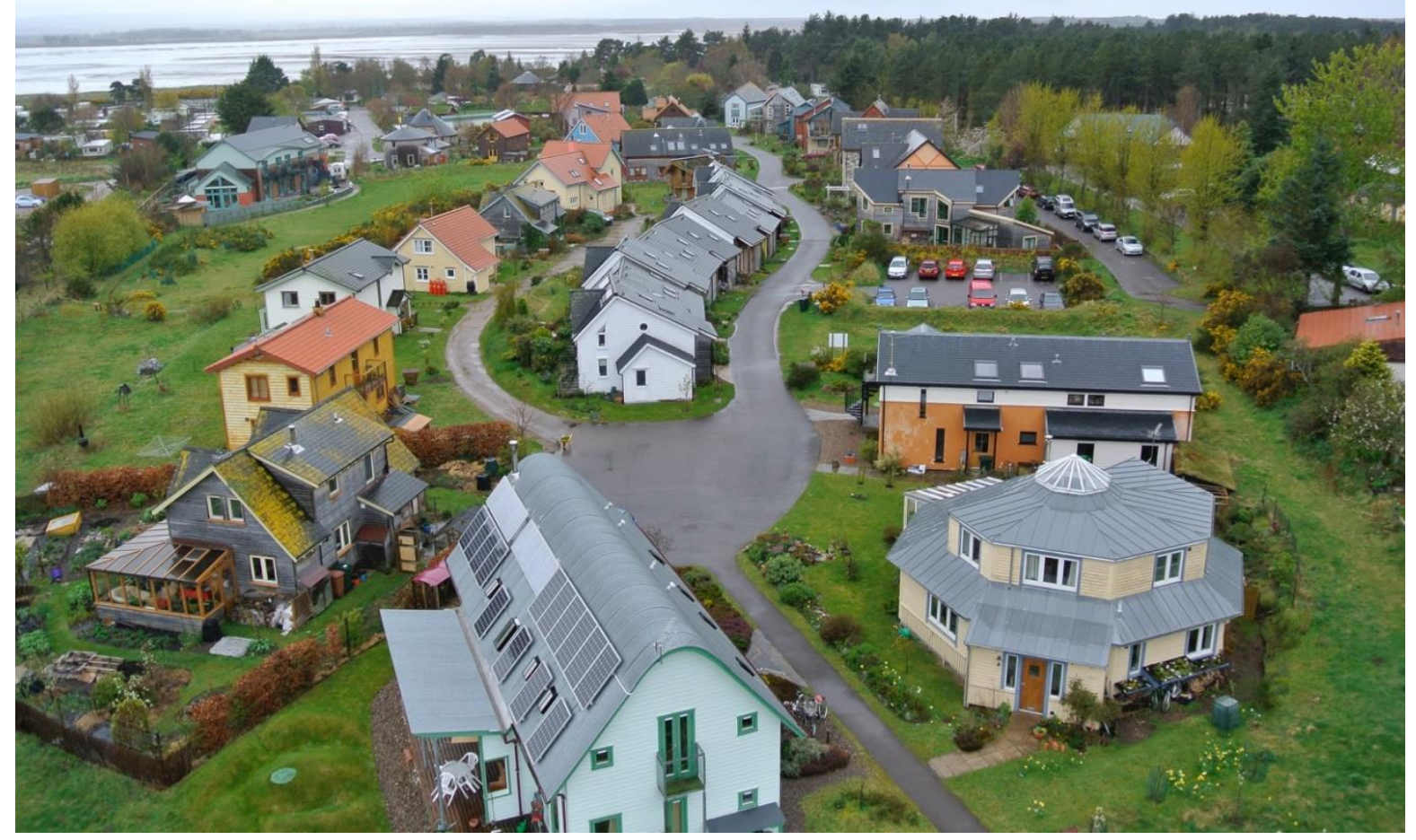

Şekil 4. Findhorn ekoköyü (www.findhorn.org).

Düzenlediği olağanüstü eğitimler ile yılda 30.000 kadar insana ulaşan bu ekoköy, bilgiyi yayma misyonu açısından en başarılı ekoköydür. Findhorn ekoköyünün bulunduğu yerde, gelgit nedeniyle denizin sürekli yükselip alçalması sonucu kum tepeleri bulunmaktaydı. Ekoköyün ilk kurucuları bu bölgede karavanlarda yaşarken zamanla sayılarının artması nedeniyle yeşil yapı ilkeleri doğrultusunda birkaç yapı inşa etmişlerdir (Zeybek, 2015).

Findhorn'un da kuruluş aşamasında yer seçimine son derece önem verildiği söylenemez. Birkaç kişinin manzarasından hoşlanarak, bir karavan park yeri şeklinde değerlendirdiği bir mekânda bu proje hayata geçmiştir. 


\section{- Crystal Waters}

Crystal Waters Ekoköyü 1984 yılında, 650 dönümlük bir arazide, Mary Nehri kıyısında, Maleny ve Woodford şehirlerine yaklaşık $26 \mathrm{~km}$ uzaklıkta tesis edilmiştir. Yerleşke permakültür ilkeleri doğrultusunda tasarlanmış olup özel konutlar ve ortak konut projeleri içermektedir. Nüfusu 200’ü geçmiştir. Ekoköy, yabani hayata açık bir yapıya sahiptir. Kangurular ve birçok kuş, sürüngen türleri yerleşke içinde istediği gibi dolaşabilmektedir. Ekoköydeki "No cats \& dogs" uygulamasının bu zenginliği sağladığı düşünülmektedir (Crystal Waters, 2018). Ziyaretçilerin evcil kedi ve köpeklerini getirmesi, bu hayvanların kendi alanlarını işaretleyerek bölge savaşına girebilmesi, sahibini bu alan içinde şiddetle koruması ve köy çevresindeki ekolojik dengeyi olumsuz etkileme ihtimali yüzünden yasaklanmıştır (Şekil 5).

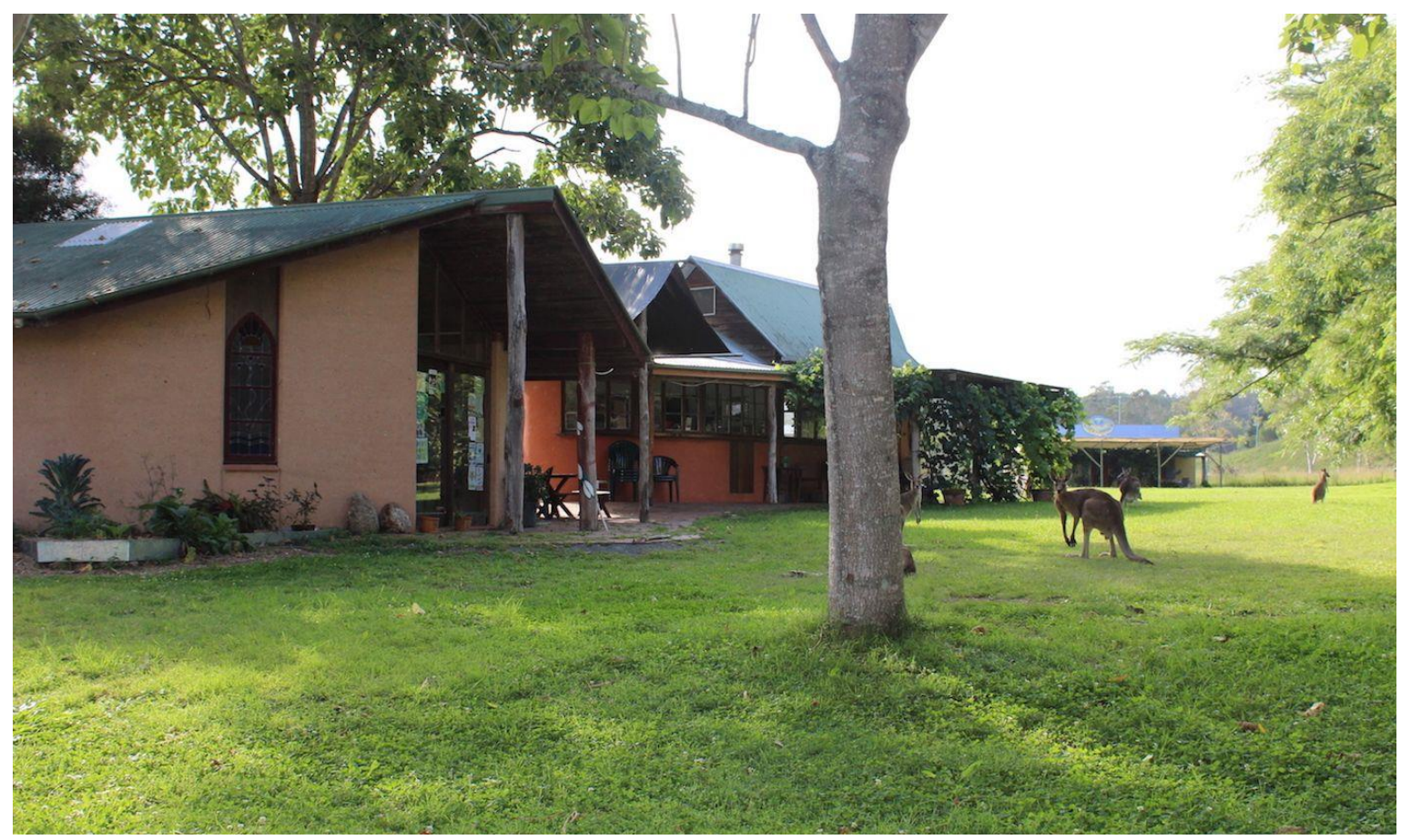

Şekil 5. Crystal Waters permakültür köyü (www. Crystalwarers.org.au).

1984’te, dünyanın ilk permakültür köyü olarak kurulmuştur. Kişi başına düşen en fazla karasal ve ıslak verimli alana sahip ekoköydür (Zeybek, 2015). Aşırı kuraklıktan muzdarip bir bölgede Crystal Waters, karmaşık bir kanallar ağı oluşturarak, gelişmekte olan akarsulara ve göllere yağmur suyunu karıştıran 1şıltılı bir vaha olarak öne çıkmaktadır (Litfin, 2018).

\subsection{Mevcut Bir Yerleşimi Ekoköye Dönüştürme Projeleri}

Bu başlık altındaki girişimler, yine bir önceki başlıkta olduğu gibi, niyet komünleri tarafından terk edilmiş ya da çok az sayıda yaşayanı bulunan köyleri ekoköye çevirme stratejisi ile geliştirilen projelerdir.

\section{- Sieben Linden}

Sieben Linden ekoköyü Almanya'daki en ünlü girişimlerden biridir. 1989 yılında "kendi kendini sürdürebilen, ekolojik bir köy” fikri ile yola çıkılmıştır. Farklı düşüncelere sahip birçok ilgili tarafından oluşturulan çekirdek grup, 1993 yılında Altmark'ta (Sieben Linden'in 25 km kuzeyinde) Groß Chüden proje merkezini satın almış ve burayı planlama aşamasını tamamlamak ve doğrudan topluluk deneyimi yaşamak için bir üs haline getirmişlerdir. 1997 yılının Mart ayında, bu proje için mülk satın alınmış, ardından 1997 yılının Haziran ayında Sieben Linden'a minibüsle taşınılmış. İlk olarak mevcut eski çiftlik, ekolojik yapı kriterlerine göre topluluk binasına ve bölgesel merkeze dönüştürülmüştür. Bu yapı toplum yaşamı ve ekolojik temalı seminerlerin merkezi olmuştur. 1999'dan bu yana ek altyapı bileşenleri kurulmuştur: yollar, kuyular, elektrik ve telefon hatları, bitki drenaj sistemi, gölet, amfi tiyatro, rüzgâr santrali dikimi vs. (Sieben Linden, 2018).

Sekiz hektarlık arazi üzerinde sürekli olarak evler, diğer konuk odaları ve ticari binalar inşa edilmektedir. 2017 itibariyle, Sieben Linden'da 11 adet çoklu aile konutu, bölgesel seminer merkezi, meditasyon evi ve diğer küçük 
binalar (ahşap işleri, at ahırları, yaz mutfakları vb.) bulunmaktadır. 1998 yılında kiralanan Poppau'daki çiftlik, başlangıçta bir geçiş bölgesi olarak hizmet etmiştir. Şimdi, Sieben Linden ekoköyü ile yakından bağlantılı olan ve yavaş yavaş yenilenen başka bir topluluğa aittir (Şekil 6).

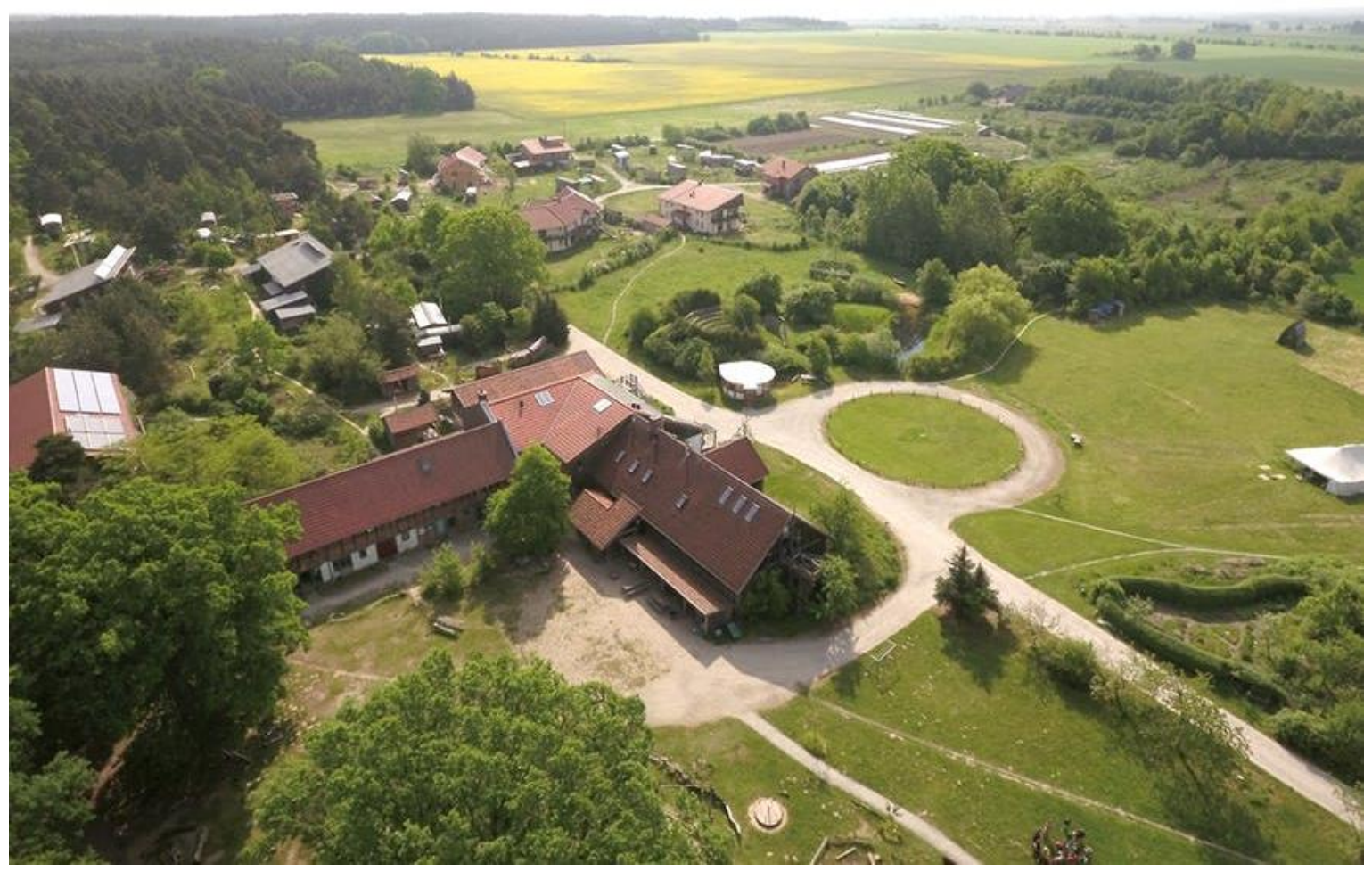

Şekil 6. Sieben Linden ekoköyü (www.siebenlinden.org).

Kassel Üniversitesi tarafından ekolojik ayak izi üzerine yapılan bir çalışmada, Sieben Linden'da yaşayan birinin, bir Alman vatandaşından ortalama üç kat daha az ekolojik ayak izi bıraktığı ortaya konmuştur. Özellikle vegan / vejeteryan diyet, araba paylaşımı, uçak yolculuklarından kaçınma ve yapıların iyi izolasyonu sayesinde bu başarıyı sağlayabilmektedirler (Sieben Linden, 2018).

Günümüzde 140 kişinin yaşadığ Sieben Linden yavaş bir hızla büyüme hedefinde olan bir yerleşimdir. İnternet sitesinde neden bu araziyi seçtiklerine dair net bir bilgi paylaşılmamıştır. Bunun yerine toplum yapısı, alan kullanımları, yapı teknikleri, ekolojik ayak izini indirgeyen yöntemler üzerinde durmuşlardır. Lakin mevcut, terk edilmiş bir köyü satın alarak bu projeyi başlattıklarından bahsetmişlerdir.

\section{- Mbam Ekoköyü}

Sineg-Saloum deltasında, Senegal'in en büyük iki akarsuyunun birleştiği yerde bulunan Mbam, yaklaşık 3.000 kişiye ev sahipliği yapmaktadır. Deltanın hassas ekosisteminin merkezinde mangrov ormanları vardır. Bunlar, 1980'lerin ortalarında, yaşanan sert bir kuraklığın sadece bitkilere zarar vermekle kalmayıp, aynı zamanda bu ağaçların kesilerek çeşitli sektörlerde kullanımının artması nedeniyle, bölge ekosistemi göz ardı edilemez bir baskı altına girmişti. Mangrovların sayısının azalması ve alana göç ile artan nüfusun bir sonucu olarak bu alanların çeltik tarlalarına dönüştürülmesi uzun sürmemişti (Dawson, 2006).

Mangrovlar, diğer kara bitkileri arasında nadir rastlanan, tuzlu suda yaşayabilme özelliğine sahiptir. Mangrovlar tuz filtresi olarak öyle etkilidir ki, çevresindeki toprakta biriken tuzu rahatlıkla bertaraf edebilir. Çeltik tarlalarında kullanılan gübrelerin yeteri kadar topraktan yıkanamaması ile tuzlanma sorunu ortaya çıkmıştır. Su yollarının tuzlanması ve geçimlerini etkileyecek dereceye ulaşan toprak erozyonu ile birlikte, yerli halktan bir grup insan daha sürdürülebilir kalkınma ihtiyacı olduğuna karar vermiş ve Küresel Ekoköy Ağı ${ }^{7}$ 'nın (GEN) Senegal ulusal şubesine danışmıştır. Civar köylerde yaşayan yerel halk, projelerin tasarım ve teslimatının tüm yönlerine girdi olarak, toplumun çeşitli başarıları gerçekleştirmesine tam katılım göstererek yardım etmiştir.

${ }^{7}$ Ing. Global Ecovillage Network. 
Daha sürdürülebilir tarım teknikleri oluşturmanın ve güneş firınları kurmanın yanı sıra topluluk, mangrov restorasyonu ve yönetimi konusunda özellikle başarılı olmuştur. Mbam, bölgesinde ekolojik mücadele ile ilgili mükemmel bir merkez haline gelmiştir ve köylüler artık çevredeki bölgelere sürdürülebilir mangrov restorasyonunda eğitim vermektedir. GEN tarafindan desteklenen köy, aynı zamanda Küresel Çevre Fonu tarafından desteklenen biyogaz sistemleri oluşturmaya başlamıştır (Litfin, 2017).

Mbam'ın hikayesine bakıldığında, yıllardır orada yaşayan halk, her geçen gün kötüye giden ekolojik denge nedeniyle ya yaşadıkları yeri terk etmek ya da kalıp bu durumu düzeltmek için mücadele etmek zorunda kalacaktı. Kalıp mücadele etmeyi seçmiş ve başarılı olmuşlardır. Mangrov ağaçlarının sayısını çoğaltıp toprağı ıslah ederek başladıkları iş, şu an bölgenin önde gelen bir ekolojik eğitim merkezi olmalarını sağlamıştır (Şekil 7).

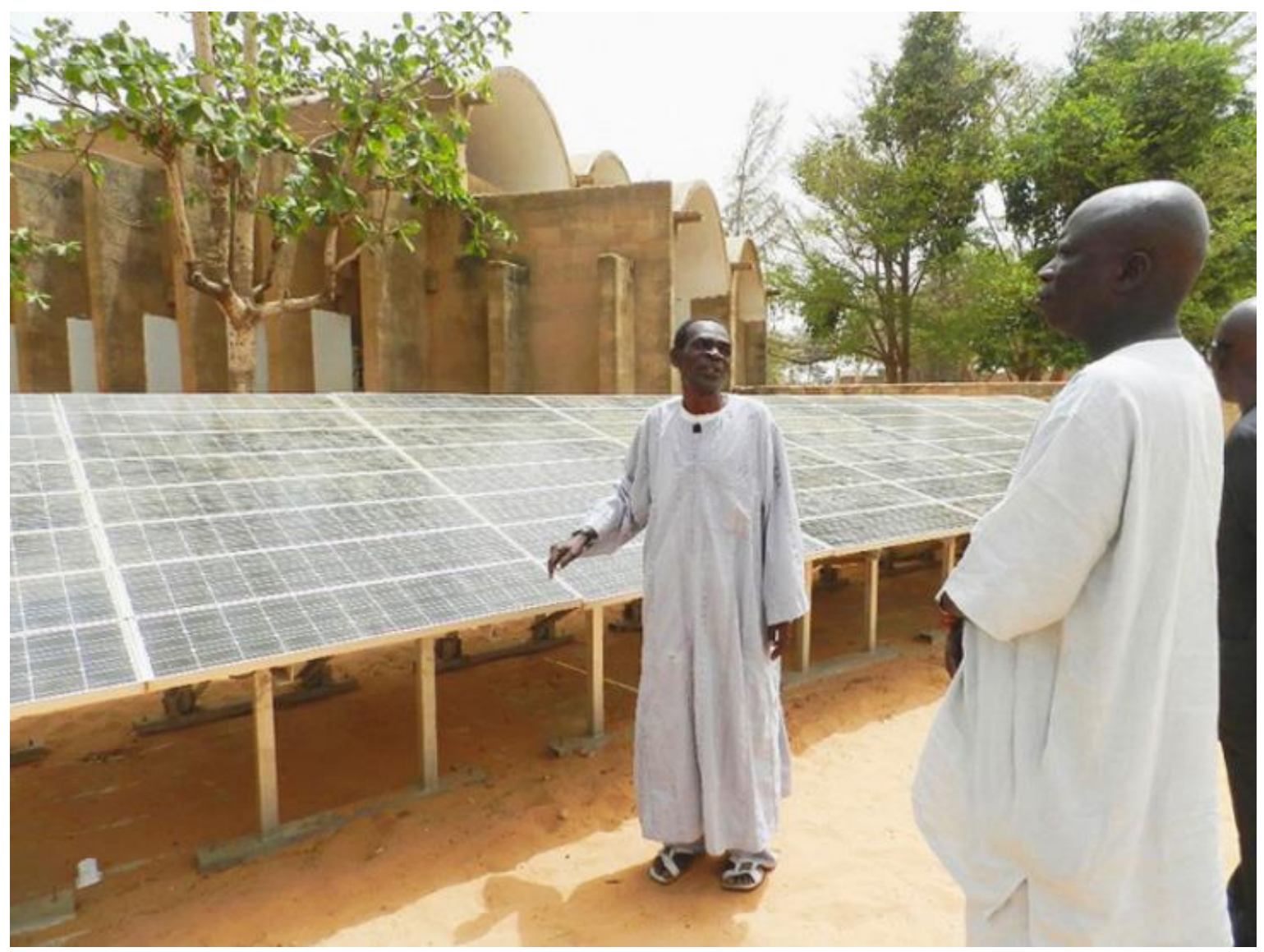

Şekil 7. Mbam ekoköyü (gen-africa.org).

\section{- Solheimar Ekoköyü}

Solheimar ekoköyü, İzlanda'nın güneybatısında, Reykjavik'in 80 km doğusunda yer almaktadır. Solheimar'ın kurucusu Sesselja Hreindís Sigmundsdóttir 5 Temmuz 1902'de doğmuştur. Danimarka, İsviçre ve Almanya'da okuma ve çalışma imkânı bulmuştur. Pedagoji, çocuk bakımı ve anaokulu eğitimi konularında çalışmalara katılan Sesselja, aynı zamanda zihinsel engelli ${ }^{8}$ insanlar için bakım, antropozofi ${ }^{9}$ (insan bilgeliği) ve ekoloji konularında da kurslara katılarak kendini eğitmiştir (Solheimar, 2018).

\footnotetext{
${ }^{8}$ Mentally Challenged: burada aslında tam olarak zihinsel engelli denmiyor. "Zihinsel zorlukları olan insanlar" gibi bir tabir var. Bunun içinde ögrenme ve odaklanma zorluğu çeken, farkındalığı zayıflamıș bireylerden bahsediliyor. Türkçe literatürde "zihinsel zorlukları olan insanlar" şeklinde bir tabir bulunmadığ için bu şekilde çevrilmiştir.

9 Antropozofi, Avusturyalı filozof Rudolf Steiner (1861-1925) tarafindan kurulan ve "ezoterik bilim" olarak da anılan antropozofi, fizik ötesi fenomenleri, doğa bilimlerinin fizikî dünyayı araştırdığı ve tanımladığı kesinlik ve açıklıkta araştırmayı ve tanımlamayı hedefleyen bir fikir akımıdır. Terimin kökleri Yunanca anthrōpos (insan) ve sophia (hikmet) sözcükleridir. Steiner, yaklaşımını "bilimsel yöntemler kullanılarak yapılan ezoterik gözlemler" olarak tanımlamıştır. Söz konusu düşünsel temellendirme, 1910'lar ve 1920'lerde bir antropozofik mimarlığın doğuşuna sebep oldu. Antropozofik mimarlığın en belirgin örneği, Basel yakınlarındaki Dornach'ta bulunan "Goettheanum" adlı yapıdır. İddialarının farklılığına karşın, ekspresyonist mimarlığa bir benzer (Wikipedia, 2018).
} 
1930'da Sesselja İzlanda'ya taşındığında, Danimarka, Almanya, Hollanda, İngiltere ve İsviçre'de organik tarım ve antropozofi hakkında birkaç kişi ile temas halinde kalmış ve bu ülkeleri düzenli olarak ziyaret etmiştir. İngiltere'deki Camphill hareketinin kurucusu Dr. Karl König, Norveçli Sólveig Nagel ve Finlandiya'dan Carita Stenback ile karşılaşmıştır. Bu üç kişi, zihinsel engelli kişilerle ilgili konularda kendi ülkelerinde öncüleri olmuşlardır. Zamanla Sesselja, İzlanda'daki zihinsel engelliler için pedagoji, sanatsal ifade ve bakım alanlarında öncü olmuştur. Dahası hem İzlanda'da hem de İskandinav ülkelerinde organik bahçeciliğe (daha sonra biyodinamik çiftçiliğe) başlayan ilk kişi olduğu için çiftçiliğin gelişime büyük katkısı olmuştur. İlk İzlandalı çevreci olarak bilinmektedir (Solheimar, 2018).

Gudmundur Einarsson liderliğindeki İzlanda Kilisesi Çocuk Bakım Komitesi, 31 Mart 1930 tarihinde Hverakot olarak bilinen araziyi satın almıştır. Hverakot, yaklaşık 250 hektarlık bir alana sahiptir ve 37 hektarlık alan kentleşme için planlanmıştır. Sesselja 1930'da henüz arazide uygun bir yapı bulunmamasına rağmen, alanı kiralamış ve Solheimar'ı kurmuştur (Şekil 8). Kısa süre içinde 10 çocuğun terapiye alınmasını sağlamıştır. Başta, ahşap yapılarda barınma ihtiyacını giderilirken, 1930'un sonlarına doğru, 1sınmak için jeotermal enerjiyi kullanan Solheimar Evi (Solheimahus) inşa edilmiştir (Solheimar, 2018).

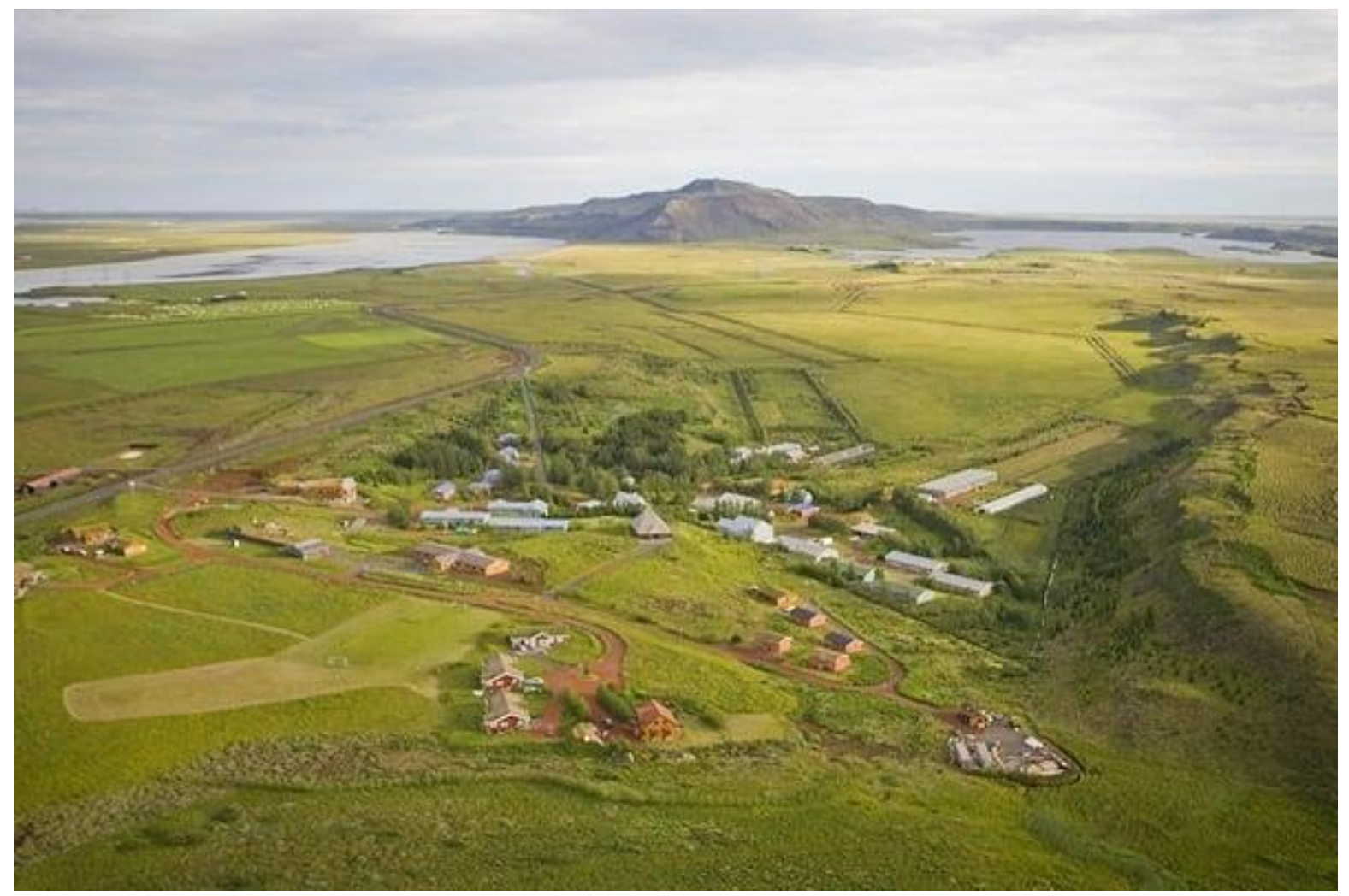

Şekil 8. Solheimar ekoköyü (www.solheimar.is).

Böylece Sólheimar, özellikle anne ve babasını kaybetmiş veya hasta ebeveynleri olan çocuklar için bir çocuk evi olarak başlamıştır. O yıllarda İzlanda'da fiziksel veya zihinsel engelli çocuklar için pek alternatif bulunmamaktadır (Solheimar, 2018).

Sesselja, Sólheimar'ın bir kurum değil, bir ev olduğunu ve engelli insanların herkesle aynı hakları paylaştığını her firsatta vurgulamıştır. Yaz aylarında zihinsel ya da bedensel engeli olmayan çocuklar için eğitim kampları da düzenlemiştir. Engelli ve engelsiz çocukları entegre etme konusundaki kararlılığı, "sağlıklı" çocukların, sanki engellilik bulaşıcı bir durummuş gibi, özel ihtiyaçları olanlarla birlikte oynamamaları gerektiği şeklindeki geniş çaplı tartışmalara yol açmıştır. Yine de Sesselja, daha saygılı, sağduyulu nesiller yetiştirmek için böyle bir uygulamanın gerekli olduğu düşüncesinden vaz geçmemiştir (Solheimar, 2018).

Solheimar geliştikçe, kendi kendine yeten bir yerleşime dönüşme ihtiyacı hissedilmeye başlanmıştır. Kışların çok sert geçtiği İzlanda'da çoğu zaman Solheimar ile Reykjavik'in bağlantısı kesilmekteydi. Dolayısıyla ekolojik, ekonomik ve kültürel açıdan yeterli bir yerleşim olma yönünde büyük adımlar atılmıştır (Solheimar, 2018). 
Solheimar tüm yaşayan toplumların yaptığı gibi büyüyüp gelişmektedir. Amacı hala yaşam kalitesini, sakinleri için mümkün olduğunca iyi hale getirmektir ve kurucunun vizyonuna olan bağlılığ1 ile birçok yönden takip edilmektedir (Solheimar, 2018).

Solheimar dünyadaki ilk ekoköyler arasında sayılmaktadır. Halen yardıma muhtaç insanların bakımının yapıldığı, hatta bazı hükümlülerin rehabilite edildiği bir merkez olarak topluma çok değerli katkıların sunulduğu bir mekândır. Solheimar yerleşkesi, evrensel tasarım ${ }^{10}$ ilkeleri kapsamında, engelli bireylerin özgürce hareket edebilmesine olanak sağlayacak şekilde tasarlanmıştır (Solheimar, 2018).

Yukarıdaki bütün paragraflar, Solheimar'ın resmi internet sitesindeki "History of Solheimar" başlıklı uzun makaleden özetlenmiştir. Metinden anlaşıldığı üzere, Solheimar'ın yer seçiminde ekolojik ya da ekonomik kriterler değil, daha çok spritüal kriterler gözetilmiştir. Yardıma muhtaç insanların bakımının yapıldı̆̆ı bir mekân, zamanla başarılı bir ekoköye dönüştürülmüştür.

\section{- COLUFIFA}

COLUFIFA, Fransızcası Comité de lutte pour la Fin de la Faim (Açlığı Bitirme Komitesi) olan bir kuruluşun adının kısaltmasıdır (Litfin, 2018). Adından da anlaşılacağı üzere, bir ekoköy değildir. Ancak bu listeye önemli bir nedenden ötürü eklenmiştir. Daha ziyade organik tarım, mikrofinans, sitma ve ebola ile mücadelede kendi kendine yeterli olmaya çalışan 350 Batı Afrika köyünün Senegal merkezli bir ağıdır. Merkezi Faoune ekoköyüdür (Şekil 9). Günümüzde Senegal, Gine, Gambiya'daki köyler üzerinde çalışmalarını yürütmektedir (COLUFIFA, 2018)

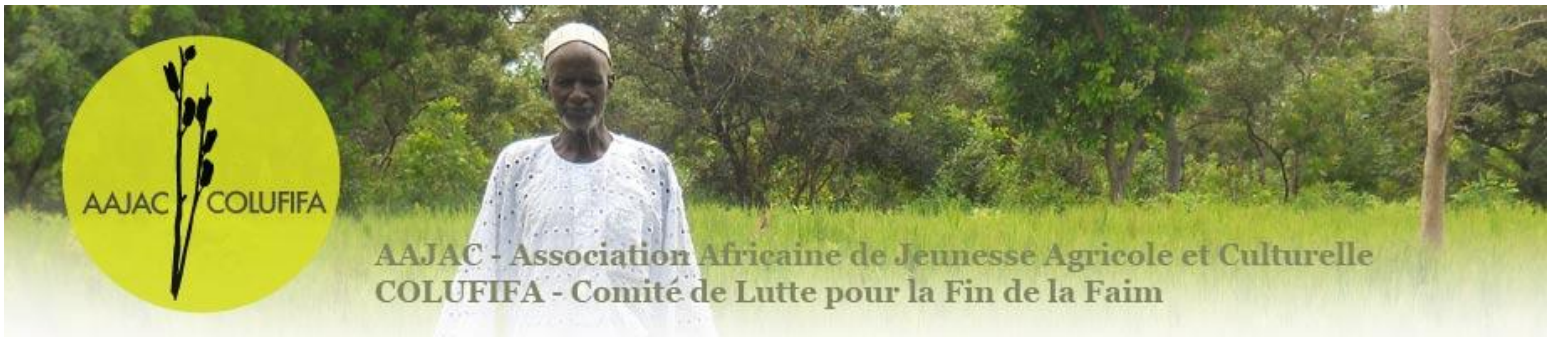

Şekil 9. COLUFIFA (www.aajac-colufifa.org).

COLUFIFA'nın temel amacı, gelişmekte olan veya yoksul ülkelerde yeni köyler inşa etmek değil, mevcutları sürdürülebilir kılmaktır. 1964'te kurulan komite ekoköy hareketini on yıllardır ön plana çıkarırken, Küresel Ekoköy Ağı'nın kurulmasının ardından bu ağa katılmıştır (Litfin, 2018).

Ne var ki COLUFIFA'nın yoksul köylüleri ekoköyler arasındaki en düşük ekolojik ayak izine sahip olsalar da mecburen bu şekilde yaşamak zorunda kalmışlardır. Çünkü zorlu iklim şartları, işsizlik ve yoksulluğun akıl almaz boyutlara ulaştığı bu köylerde başka bir yaşam modeli kurmak mümkün görünmemektedir. Bu köylerdeki çoğu erkek Avrupa'ya ya da Amerika'ya iş bulmaya gittiği için topluluklarda büyük kopmaların olduğu görülmüştür. Bu nedenle COLUFIFA'nın yaptığı en akıllıca şey, kadınları eğitmek olmuştur (Litfin, 2018).

\section{- ZEGG}

Berlin'den 90 dakikalık tren mesafesinde, Belzig kasabasının dışında, 1991 yılında kurulan ZEGG - Zentrum füe esperimentelle Gesellschaftsgestaltung (Deneysel Kültürel Tasarım Merkezi), 80 küsur kişilik bir yerleşimdir (Şekil 10). Birçok ekoköy daha dürüst ve şeffaf iletişim kurma yollarını kullanarak üyelerin arasında güvene dayalı bir kültür geliştirmenin yollarını arar. Bu, Alman ekoköyü ZEGG’in önceliklerinden biridir (Litfin, 2017).

\footnotetext{
${ }^{10}$ Evrensel Tasarım kavramı İngilizcede farklı isimlerle ifade edilmektedir. Bu nedenle Türkçede de farklı ifadelere karşılık gelmektedir: Kapsayıcı tasarım (inclusive design), yaşam boyu tasarım (lifespan design), evrensel tasarım (universal design), herkes için tasarım (design for all) gibi.
} 


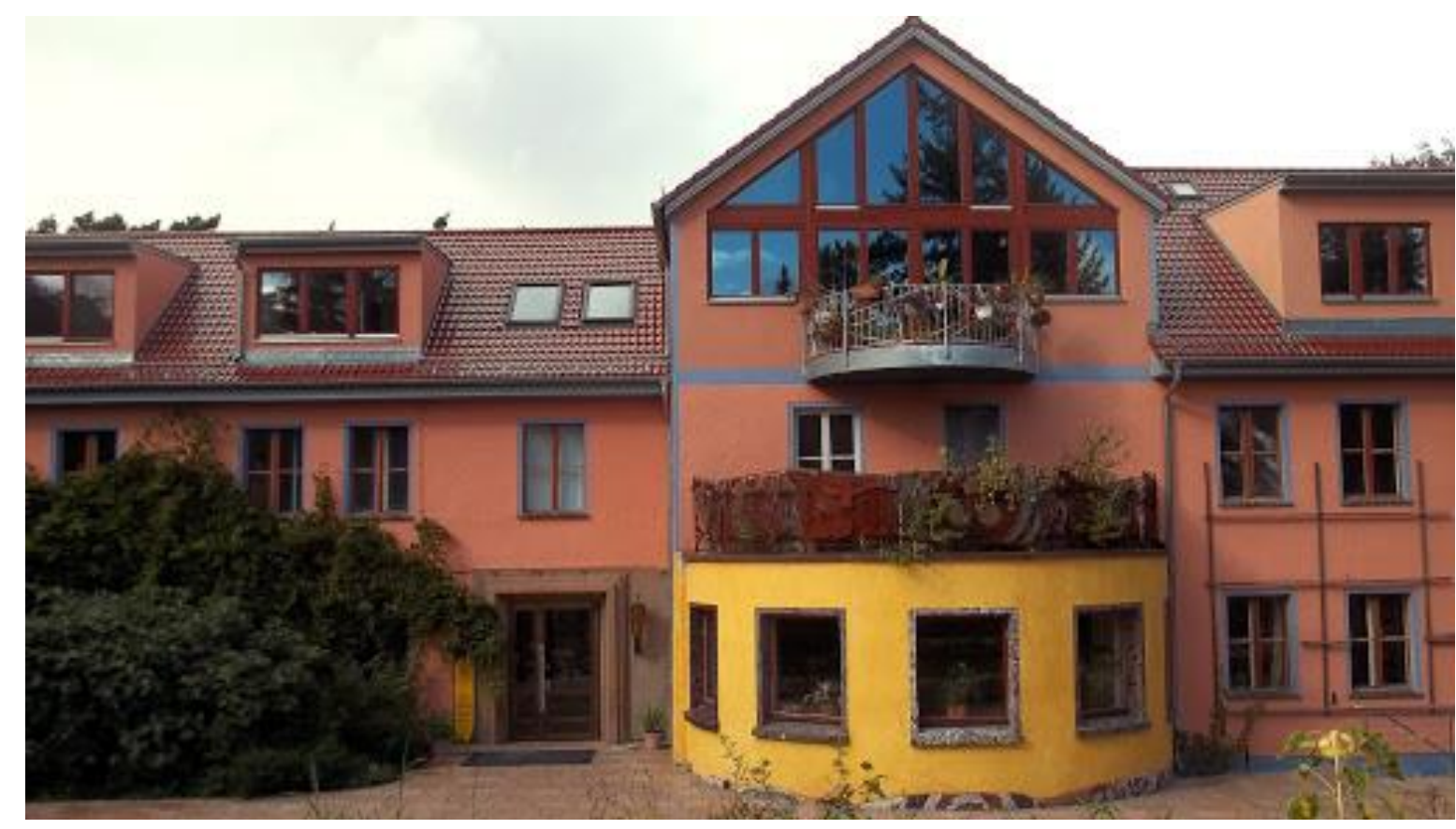

Şekil 10. ZEGG ekoköyü (www.zegg.de).

ZEGG, eski doğu Alman gizli polis teşkilatı olan STASI'nin eğitim merkezini devralmış, bölgeyi canlandırmak, bunu bir kaynak ve kazanca dönüştürmek için çok emek harcamıştır. Der Winkel isimli özerk bir okulun kurulması için yerel girişimlerde önemli görevler üstlenmiştir. Der Winkel aşırı sağcılığa ve şiddete karşı hoşgörüyü savunup mülteciler ve sığınmacılarla hazırlanan projelere, adil ticaret ürünlerini, topluluk destekli tarımı ve her türlü kültürel etkinliği destekleyen kampanyalara, yerel takas ticareti sistemlerine ve ormanın içindeki bir çocuk yuvasına ev sahipliği yapmaktadır. ZEGG ayrıca bölgedeki diğer küçük topluluk projeleri için bir arkadaşlık, dayanışma ve destek ağı kurmuştur. Bölgesine yaptığı katkılardan dolayı 2005 yılında Avrupa Ekoköy Mükemmellik Ödülü’ne ${ }^{11}$ layık görülmüştür (Dawson, 2006).

Çalışmalarından da anlaşılacağı üzere ZEGG, ekoköylerin bulundukları bölge ile daha fazla bütünleşmesini savunmaktadır. Berlin duvarının yıkılmasının ardından Doğu Alman bölgesindeki gizli bir polis teşkilatının terk edilmiş binasını dönüştürmek için çabalayan topluluk, aslında yer seçimi konusunda siyasal bir hamle ile, biten kötü bir dönemin izlerini en marjinal şekilde silmeye çalışmaktadır.

\section{Tartışma ve Sonuç}

$\mathrm{Bu}$ örneklerden çıkarılması gereken bazı dersler bulunmaktadır. Örneğin, planlama mevzuatı birçok gelişmiş ülkede oldukça katıdır; bu nedenle profesyonel destek olmaksızın yeni yerleşkeler oluşturmak oldukça zordur. Profesyonel destek almak için de topluluğun maddi kaynaklarını bir süredir oluşturuyor olması gerekmektedir. Bu konuda İrlanda'daki The Village güzel bir örnek teşkil etmektedir. Yer seçimi aşamasında arazinin ekolojik karakterinden ziyade hükümetin planlama stratejisi daha belirleyici olduğu için zaman kaybetmek yerine daha mantıklı bir yol seçerek işin uzmanlarına danışmışlardır. Bunu sağlayabilmelerindeki temel araç ise, proje fikir aşamasındayken oluşturdukları risk sermayesidir. Yeni kurulan topluluklar yasal izni bu yöntemle aldıktan sonra, ekoköylerindeki mekânları oluşturmak ve yönetmek için daha özgür olabilmektedirler. Örneğin, The Village'taki inşaat işleri, ağırlıklı olarak bireylerin sorumluluğundadır. Bazı üyeler kendi konutlarını inşa edebilmektedirler.

Sieben Linden'ın ilk hedefi, yaşanılan bölgede çok küçük bir ekolojik ayak izi bırakarak yaşamayı deneyimlemekti. Projenin öncüleri 1986 yılında toplantılara başlamış, net hedefler koymak için çok yoğun bir şekilde çalışmıştı. Proje sürecinde ekolojik inşaat teknikleri ve kaynakların döngüsel dolaşımı gibi, yaşamın tüm alanlarında kendine yeterliği deneyimlemeyi sağlayan yöntemler tercih edildiğinden, mevcut bir yerleşkeyi iyileştirmek yerine yeni bir yerleşke kurulmasına karar verilmişti. Yürürlükteki planlama mevzuatı, satın alınabilecek yeterli arazi olmaması ve açık fikirli köylerin olduğu bir bölge bulamamak gibi engeller yüzünden bu süreç oldukça uzun sürmüştür. Topluluk üyeleri 1997 yılında Poppau köyünün belediye başkanı ile görüşmüş

\footnotetext{
${ }^{11}$ Ing. European Ecovillage Excellence Award.
} 
ve köyün bitişiğindeki, birkaç yapının bulunduğu 22 hektarlık araziyi satın almışlardır. Zamanla arazilerini büyütmüşler ve yeni yapılar inşa etmeye başlamışlardır. Sieben Linden, ekolojik yapılar konusunda oldukça başarılı bir yerleşimdir. Avrupa'da sadece saman balyaları kullanarak inşa edilen tek üç katlı yapı burada bulunmaktadır. Yalnız, yine Almanya'daki mevcut mevzuata göre saman balyasıyla ev yapımı için yapılan tüm başvurular tek tek değerlendirilmekte, bu da zaman ve para açısından kayba neden olmaktaydı. Kassel Üniversitesiyle işbirliği içinde yapılan çalışmalar sonucunda, Sieben Linden'da uygulanan bu yapı tekniğinin karbondioksit salınımını önemli derecede düşürdüğü tespit edilince mevzuatta da bazı değişiklikler gerçekleştirilmiştir.

Auroville'in bulunduğu coğrafyada muson mevsimi oldukça sert geçse de, tıpkı Mbam gibi, bulundukları araziyi terk etmeyi değil, kalıp zorluklarla mücadele ederek ve ekosisteme uyum sağlayarak varlıklarını sürdürebilmektedir. Crystal Waters da kuraklığın korkutucu boyutlara ulaşabildiği bir iklimde başarıyla varlığını sürdürebilmektedir. Hakeza, Solheimar da kış şartlarının çok zorlu geçtiği bir coğrafyada bulunmaktadır. Ithaca ekoköyü, kentsel baskının hissedildiği bir bölgedeyken Solheimar bundan oldukça uzaktadır.

Özetle, incelenen bu ekoköylerin arazi seçimi aşamasında, özellikle yaşaması kolay, iklimi insan için elverişli olan bölgeleri tercih etmeleri söz konusu olamamıştır. Bilakis, bu ekoköylerde yaşayan insanlar, her coğrafyada sürdürülebilir bir yaşamın kurulabileceğini savunmaktadır. Aynı vadideki iki ekoköyün bile tasarımı, işleyişi farklı olabilecekken, dünyanın tüm bölgeleri için tek bir modelden bahsetmek imkânsızdır.

Bu çalışmada bahsi geçen ekoköyler, dünyada adı en çok duyulanlar arasındadır. Her birinin yer seçimi hikâyesi birbirinden farklıdır. İster niyet komünleri tarafından boş bir araziye kurulsun, ister var olan bir yerleşkeyi ekoköye dönüştürme projesi olsun, her biri farklı zorluklarla mücadele etmiştir. Dolayısıyla bir ekoköy projesi için yer seçiminde bir standart oluşturmak imkânsız gibi görünmektedir. Auroville ekoköyündeki arşivden sorumlu Gilles Guigan’ın da dediği gibi; “ekoköy için yer seçmek, bazı alanları diğer alanlardan daha üstün görmek, her şeyden önce etik değildir”.

\section{Kaynaklar}

1. Auroville. (2018). Auroville: The City of Dawn. Erişim: 09.07.2018. https://www.auroville.org/.

2. Bokaer, J. (1991). Ecovillage at Ithaca. A model for land conservation and sustainable neighbourhood development. Prepared by: EVI, C/o Citizens Network, Anabell Taylor Hall, Cornell University. Ithaca, New York, 14853. September, 1991. 16p.

3. COLUFIFA (2018). COLUFIFA - Comite de Lutte Pour la Fin de la Faim. Erişim Tarihi: 11.07.2018. http://aajac-colufifa.org/information-in-english/.

4. Crystal Waters (2018). “Crystal Waters Permaculture Village”. Erişim Tarihi: 12.07.2018. https://crystalwaters.org.au/.

5. Dawson, J. (2006). Ecovillages: New Frontiers for Sustainability. Green Books, İngiltere. 2006.

6. GEN (2020). Dimensions of sustainability. Global Ecovillage Network official website: https://ecovillage.org/projects/dimensions-of-sustainability/. Erişim tarihi: 18.03.2020.

7. Jackson, H. and Svensson, K. (2002). Ecovillage Living: Restoring the Earth and Her People. UIT Cambridge Ltd.; 1st edition. 180p. 2002.

8. Litfin, K. (2017). Ekoköyler: Sürdürülebilir bir toplum için dersler. ALFA Basım Yayım Dağıtım, İstanbul. Çev: Pınar Ercan. 2017.

9. Litfin, K. (2018). Ecovillage Book. Web Sitesi: https://ecovillagebook.org/ecovillages/colufifa/. Erişim Tarihi: 11.07.2018.

10. Sieben Linden (2018). Ökodorf Sieben Linden. Erişim Tarihi: 09.07.2018. https://siebenlinden.org/en/ ecovillage-2/history/. 
11. Solheimar (2018). History of Solheimar Ecovillage. Erişim Tarihi: 09.07.2018. http://www.solheimar.is/en/solheimar/ history-of-solheimar/.

12. The Village (2018). History of our village. Erişim Tarihi: 10.07.2018. http://www.thevillage.ie.

13. Walker, L. (2016). Ekoköy Ithaca. Yeni İnsan Yayınevi, Ekoloji Serisi. Çev: Orhan Tuncay. 272s. 2016.

14. Wikipedia (2018). Antropozofi. Erişim Tarihi: 09.07.2018. http://www.wikizero.net/index.php?q= aHR0cHM6Ly90ci53aWtpcGVkaWEub3JnL3dpa2kvQW50cm9wb3pvZmk.

15.Zeybek, O. (2015). Ekoköy Akımı: Tarihi Gelişimi ve Kent Ölçeğinde Uygulanabilirliği Üzerine Bir Araştırma. Ankara Üniversitesi Fen Bilimleri Enstitüsü Yüksek Lisans Tezi. Ankara, 2015. 